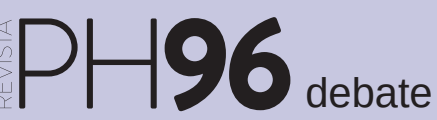

a debate Memoria democrática en la construcción de la historia y el patrimonio

| coordina Josefina Cuesta Bustillo

\title{
Memoria histórica y democrática con perspectiva de género
}

\author{
M. ${ }^{\text {a }}$ Cristina Ferrer González | docente e investigadora \\ URL de la contribución <www.iaph.es/revistaph/index.php/revistaph/article/view/4297>
}

El relato del devenir histórico ha llegado sesgado, incompleto e incluso, falseado, debido a que sistemáticamente se ha ignorado, negado o manipulado la aportación de las mujeres en la construcción del conocimiento y del desarrollo socioeconómico, tanto en el ámbito de la ciencia, la literatura, el arte o la historia. En consecuencia, la construcción de su memoria colectiva ha sido mermada, y sin lugar a dudas, esta exclusión obliga, no a escribir una nueva historia, sino a reconocer, incorporar, visibilizar y difundir toda su aportación. Ponerla en valor.

En su artículo 20, la Ley de Memoria Histórica y Democrática de Andalucía establece, como prioritaria, la investigación y pone el acento en aquella que tiene la mujer como protagonista, en un gesto de discriminación positiva, para compensar la invisibilidad en el relato histórico e incluso en el discurso de la Transición democrática.

Las mujeres tuvieron una vinculación importante con los movimientos sociales, civiles, obreros y políticos, entre otros. Pagaron un plus por representar los nuevos modelos de feminidad, más cercanos a la igualdad real, que rompían con los paradigmas tradicionalistas. En cualquier sociedad, y en la nuestra también, romper moldes, normas o estereotipos es una acto de heroicidad, y por ello sufrieron doble victimización, la de su ideología y la de ser mujer, dado que se querrá imponer un modelo patriarcal y único de ser mujer. Los castigos de género son comunes e inherentes a todo conflicto bélico y suponen un mayor grado de violencia contra las mujeres, que abarca desde la violencia sexual a la física y psicológica, pasando por las humillaciones y vejaciones.

La memoria histórica y democrática de un pueblo es un auténtico patrimonio material e inmaterial donde los recuerdos adquieren voz, los miedos se sienten, las ilu- siones se dibujan, las experiencias se comparten, se identifican, se respetan y se reivindican y donde los silencios obligados alzan su voz recuperando su identidad. El recuperar la memoria histórica y democrática con perspectiva de género es un acto de justicia, un deber, no solo de las instituciones políticas o gobiernos sino de las históricas, culturales y sociales, implicando a la ciudadanía en esa incorporación, con el objetivo firme de la recuperación y reparación de ese colectivo más velado.

No considero que recuperar y poner en valor una memoria implique el olvido de otras, y mucho menos que incorporar el género a los estudios e investigaciones sea infravalorar la aportación masculina. Sino más bien, como decía Montserrat Roig, cuando hablaba de las grandes silenciadas de la Segunda República, así se sustituye el tiempo de silencio por el tiempo de la palabra.

En la última década son muchos los trabajos que contemplan, relatan y vivencian la memoria democrática desde un perspectiva inclusiva, incorporando colectivos que, anteriormente, no eran tenidos en cuenta o eran tratados de manera muy marginal como son el colectivo de mujeres, el de migrantes y extranjeros, colectivos de diversidad cultural, sexual o religiosa. Antes se relataba más la memoria unilateral, patriarcal, heterosexual y con hegemonía de la Iglesia Católica.

Jorge Wagensberg afirmó que "Cambiar de respuesta es evolución. Cambiar de pregunta es revolución". Quizás es el momento de cambiar la pregunta. 